\title{
Research on the Conception of History and Methodology of Economic
}

\author{
History \\ Jiawen Zhang ${ }^{1, a}$ \\ ${ }^{1}$ Bishop Amat Memorial High School, 14301 Fairgrove Avenue, La Puente, CA 91746 \\ a email:
}

Keywords: Economic History; Conception of History; Methodology

\begin{abstract}
As a non-mainstream subject, economic history has not yet been paid much attention by the economists. However, with the development of economics, the research of economic history became more and more important. Therefore, it is necessary to systematically summarize the historical view and research methods of the economic history. Based on author's research and induction, this paper first analyzes the historical view of economic history, and then discusses the methods of economic history research, in order to provide a reference for the study of economic history.
\end{abstract}

\section{Introduction}

In the subject catalogue published by China's Ministry of Education, there are nine secondary disciplines under Theoretical Economics. History of economic thought and economic history are ranked second and third respectively. For a long time, these two disciplines have been studied by their own definition, object, and method, forming a distinctive feature. From the early 1940s, some scholars started to advocate the study of economic history. Since then, the name of the economic history starts to frequently appear on different occasions, causing the attention and discussion of the academic community. After a study on the history of economic thought, the author makes a summary of the historical view and methodology of economic history in this paper.

\section{Conception of History}

In the academic circles of China, it is Wang Yanan who first put forward the concept of economic history. He pointed out in 1940s: The study of Chinese economy needs to be based on three kinds of science which are economics, economic history and the history of China's economy. About economic history, Wang Yanan wrote: "Modern economic history is gradually formed after the founding of the economy for a long time, strictly speaking, it is derived from the critical economics or derived from the guide. The object of economic research is the capitalist economy, which is a more developed economic form". The difference between economic history and general economics lies in: "The general economics focuses on the principle, the individual historical and social economic law, but the economic history focuses on the historical and social history of individual continued change rule. " These two are helpful to the study of the economic form of a backward society, but economic history has been successful for a more complete science.

The first person using the second concepts of economic history is Chen Shaowen. In 1985, He wrote the Review and Prospect of China's economic history, which made it clear: "China's 
economic history includes the history of China's economic history and the history of Chinese economic thought". As a science, comparative economic history has been more than a hundred years of history, and the founder of the German historical school economist Roscher (1817 - 1894), who advocated to use historical methods to study the history of the development of the national economy, emphasized the economic and legal, political, cultural and other links, and compared the characteristics of the development of the national economy.

Zhao Dexin has its own unique system of views on the definition of economic history. Overall, he believes that economic history is economic history, but, in different occasions, he believes a distinction between the definition of economic history. Firstly, the economic history is the economic history, he said in his article on the question of economic history: "Economic history is the objective process of the development of social productive forces and production relations. The economics of this process is called "History Economic".

Wu Chengming had a new idea of economic history, but he himself actually used the name, he once said in Economic History: a historical perspective and methodology in 2001, "In the west, economic history, as an independent discipline, is separated from the history of the late nineteenth Century".

Chen Zhenhan's use of the concept of economic history is also worth to mention. He said in the text of Pete and economic history: Joseph Alois Schumpeter is never known as an economic historian, but in the contemporary famous bourgeois economists, there is no one more can contribute and has a significant impact on economic theory and economic history in two ways".

\section{Methodology}

Positivism analysis method. The traditional view of positivism is: if the introduction of a conclusion on the facts P from a theory q, and this conclusion Q experimental test is true through observation, we can prove that this theory $\mathrm{P}$ is true. Keynes said in the scope and method of political economy, an empirical science, is about "what is", and it is independent of any ethics and moral judgment. In brief, the positivism is an "objective" knowledge. In the analytical framework of positivism, there is a key assumption behind the logic deduction of the economists, which can be separated from the economic operation. The analysis technique of "other conditions are unchanged", in fact, it is in between theory and practice into a hypothetical intermediary role in the test field, so it blocked the road to practical observation and empirical testing. As one of the methods used in the study of economic history, the empirical method is only applicable to the study of some fields and problems. In this range, the empirical method is valid, and beyond this range, it may be invalid. On the nature and significance of economic science published by Robbins in 1932, it is considered that the basic problem of the methodology of western orthodox economics is the test of the truth of the theory. On this issue, he made a distinction between the correctness and practicality of the theory. In his view, the correctness of a particular theory is a question which is derived from the general premise of logic. After World War II, along with the great revolution in economics, the research method of economic history has changed.

Global macro analysis method. The French Yearbook school, which started in 1930s, has entered the second generation, forming a Braudel Fernand led by the overall concept of history. The biggest innovation of the Annals School lies in the extensive absorption of sociology, economics, psychology and other theories and methods of social science, which has become a basic feature of modern western historiography. On the basis of a large number of historical facts, they hold the clue of the evolution of human history, revealing the deep reasons for the change of different social structures. For this overall macro analysis, it is not feasible if there is no theory, particular Western 
Economics and other social sciences, such as the help of Science, so it is not required to cross disciplines in this field.

Marginal analysis method. Malthus pointed out in 1814 the differential method can be used in the economic analysis. In 1824, W.Thompson used economic analysis of differential for the first time. From 1870s to early twentieth century, the marginal revolution begun, and the pioneer is Hermann Heinrich Gossen, who published a book at their own expense in 1854, namely, The Development of the Law of Human Exchange and Human Behavior. He wrote in the preface to the book:" Just like Copernicus was able to determine the orbits of celestial bodies in an infinite time, I am confident that I can point out that they are the most perfect way to achieve their goals of life must follow the road through my discovery of the human right". Marginal analysis method is to study that a change in the number of variables will have a greater impact on the changes in other variables. Using derivative and differential method to the change of incremental method in economic operation quantity, in order to analyze the relationship between the economic variables and changes in the process. Using the mathematics to set the key dependent variables in human behavior, and the model is put forward to make the relationship functional, so the introduction can be proved by the fact that the meaning. Transforming certain objects in an economic problem into basic terms, a series of propositions can be derived at last to get a proposition about the original economic object. Under the assumption of perfect competition of classical economics, marginal revenue is consistent with the average income, but in imperfect competition, monopoly and socialist planned economy, the marginal value can not be replaced by the average value. As a result, the analytical method is widely used in the analysis of economic behavior and economic variables, such as utility, cost, production, revenue, profit, consumption, savings, investment and factor efficiency, etc. It is widely used not only in the west, but also in the former Soviet Union and in China.

Analysis method of quantitative history. After the Great Depression of the United States in 1930s, more governments began to focus on gathering thousands of economic data to study. Therefore, how to analyze these thousands of economic data and find the law of the economy has became very important. Using some methods of statistics to study the economics of econometric coincides with such demand. The development of econometric in the second half of the twentieth Century influences the methods and development of economic research. J.Heckman and D.McFadden, two micro econometric economists, won the Nobel prize in 2000. Furthermore, more than half of the Nobel prize in economics was awarded to economists who had made a contribution in the mathematical model, which once again shows that the measurement of economics in the whole economic system has an indispensable position.

Comparative historical method. The study of economic history has a serious "problem" path dependence, that is because , for the "European center" and "China center", a hundred years of controversy. In recent years, as a result of many research breakthroughs, California school has become the Overseas Corps of Chinese economic history research. They actively use the research methods of comparative economic history. In the research, the theoretical analysis is added, and the innovation is carried out in the research perspective, which has aroused wide discussion and has had a great impact. For the problem "Why the first industrial revolution occurred in Europe, rather than in China", Maddison, Wang Guobin, Peng Mulan think that it is of no avail to think the single criticism of the "European central theory", it needs to make a comparative study of Chinese and Western economy, focusing on comparative study. They are known as the California school because they study and research at California University. Gunder Frank, Huang Zongzhi are classified as the school of thought. Li Bozhong, the Chinese mainland economic history researcher, is also classified as the school of thought because his teaching ideas are similar to those of them. The school is a 
academic school which is a re-evaluation of Chinese history and world history. It is a loose combination, and the scholars came from the world.

\section{References}

[1] Tang Peiji.Chinese new democratic economic history review [J]. archives of the Republic of China, 1991,03:144-145.

[2] Song Fuxiang. Zhu Qianzhi's view of history and historiography [J]. Journal of Huaiyin Normal University (PHILOSOPHY AND SOCIAL SCIENCE EDITION), 2012,06:748-753+840.

[3] Yan Ping. Some thoughts on the research work of Chinese modern economic history [J]. economic research, 1959,10:57-58.

[4] Avna Greve, Han Yi. Historical Institutional Analysis: from the perspective of economic history, the new development of institutional issues [J]. economic and social system comparison, 2003,05:30-43.

[5]Xing Long. Economic history and social history [J]. Journal of Shanxi University (PHILOSOPHY AND SOCIAL SCIENCE EDITION), 2003,04:39-43.

[6] Sun Shengmin, Xu Xiaoman. Comparative analysis of institutional changes in the economic history of the three research paradigms of [J]. history and philosophy, 2008,05:151-158.

[7] Sui Fumin. Economic History: an economic analysis method [J]. China's economic history research, 2009,02:97-103. 